\title{
Turkey Creek-A Case Study of Ecohydrology and Integrated Watershed Management in the Low-Gradient Atlantic Coastal Plain, USA
}

\author{
Devendra Amatya1, Timothy Callahan'2, William Hansen ${ }^{3}$, Carl Trettin', \\ Artur Radecki-Pawlik ${ }^{4}$, Patrick Meire ${ }^{5}$ \\ ${ }^{1}$ Center for Forested Wetlands Research, USDA Forest Service, Charleston, USA \\ ${ }^{2}$ Department of Geology and Environmental Geosciences, College of Charleston, Charleston, USA \\ ${ }^{3}$ Formerly with Francis Marion and Sumter National Forests, USDA Forest Service, Columbia, USA \\ ${ }^{4}$ Agricultural University of Krakow, Krakow, Poland \\ ${ }^{5}$ Department of Biology, University of Antwerp, Antwerp, Belgium \\ Email: damatya@fs.fed.us, callahant@cofc.edu, williamfhansen@fs.fed.us, ctrettin@fs.fed.us, \\ rmradeck@cyf-kr.edu.pl, patrick.meire@uantwerpen.be
}

Received 2 May 2015; accepted 14 July 2015; published 17 July 2015

Copyright (C) 2015 by authors and Scientific Research Publishing Inc.

This work is licensed under the Creative Commons Attribution-NonCommercial International License (CC BY-NC).

http://creativecommons.org/licenses/by-nc/4.0/

(c) (i) (9) Open Access

\footnotetext{
Abstract

Water yield, water supply and quality, wildlife habitat, and ecosystem productivity and services are important societal concerns for natural resource management in the $21^{\text {st }}$ century. Watershedscale ecohydrologic studies can provide needed context for addressing complex spatial and temporal dynamics of these functions and services. This study was conducted on the $\mathbf{5 2 4 0}$ ha Turkey Creek watershed (WS 78) draining a $3^{\text {rd }}$ order stream on the Santee Experimental Forest within the South Carolina Atlantic Coastal Plain, USA. The study objectives were to present the hydrologic characteristics of this relatively undisturbed, except by a hurricane (Hugo, 1989), forested watershed and to discuss key elements for watershed management, including water resource assessment (WRM), modeling integrated water resources management, environmental assessment, land use planning, social impact assessment, and information management. Runoff coefficients, flow duration curves, flood and low flow frequency curves, surface and ground water yields were assessed as elements of the WRM. Results from the last 10 years of interdisciplinary studies have also advanced the understanding of coastal ecohydrologic characteristics and processes, water 
balance, and their modeling including the need of high resolution LiDAR data. For example, surface water dynamics were shown to be regulated primarily by the water table, dependent upon precipitation and evapotranspiration (ET). Analysis of pre- and post-Hugo streamflow data showed somewhat lower but insignificant $(\alpha=0.05)$ mean annual flow but increased frequency of larger flows for the post-Hugo compared with the pre-Hugo level. However, there was no significant difference in mean annual ET, potentially indicating the resiliency of this coastal forest. Although the information from this study may be useful for comparison of coastal ecohydrologic issues, it is becoming increasingly clear that multi-site studies may be warranted to understand these complex systems in the face of climate change, sea level rise, and increasing development in coastal regions.

\section{Keywords}

Francis Marion National Forest, Integrated Water Resource Assessment, Water Balance, Water Quality, Eco-Hydrologic Models

\section{Introduction}

Managing forested wetland landscapes to sustain water quality, water quantity, and productivity require a detailed understanding of functional linkages between ecohydrologic processes and management practices. Watershed-level hydrologic and nutrient cycling processes are complicated by the presence of varied land features such as forests, wetlands, riparian areas, uplands and water bodies, along with multiple land uses. Despite the importance of forested wetlands, many of them have been converted in the last five decades primarily as a result of agriculture and urbanization [1]. However, hydrologic modification started with colonization and rice culture, with many of these changes still present [2]. The land use change of wetlands and streams influences hydrologic processes, as well as water quality, because wetlands affect the runoff and the transport and exchange of materials between terrestrial and aquatic ecosystems. Understanding those impacts on material storage, interception, transport and transformation are needed to manage water quality and water resources [3] [4].

The forested landscape of the lower southeastern Coastal Plain is characterized by a series of marine terraces bounded by scarps defined by a series of complex material deposits with marine, estuarine and riverine erosion affecting their composition and surface and subsurface hydrology [5]. These landscapes consist of natural and managed forests, depressional wetlands, pine flatwoods, riparian areas with bottomland hardwoods (BLH), extending to maritime forests bounded by brackish to salt marsh [6]. They are generally characterized by poorly to moderately drained high water table soils, wet sites, and low topographic relief [7]. Some of these lands have been drained artificially to lower water tables for accessibility and reduction of excessive moisture for increased crop growth [8]. Roads, ruts, and firelines also modify surface and subsurface hydrology [9]. Hillslope processes dominate the hydrology of upland watersheds, but hydrologic processes on relatively low-gradient poorly drained Coastal Plain sites are usually dominated by shallow water table positions. In fact, most of the outflows from these watersheds drain from the relatively flat marine terraces into saturated riparian areas where the water is at the surface or a shallow water table is present, meaning that total outflow depends on the frequency and duration of flooding and on the dynamics of the water table [10]-[13]. All of these processes complicate the task of quantifying the water budget components of these forested wetlands, and the need to account for the use of various water and silvicultural management practices, and interactions with surrounding uplands makes the job even more challenging.

Some of the past studies have documented hydrology and water budgets for these forested wetlands [8] [10] [12] [14]-[26]. However, most of those studies were focused on a specific issue and/or were very site specific on a field-scale basis using mostly headwater watersheds, limiting the ability to respond to broader scale, more complex and integrated issues, including applications of social sciences and needs, most of which occur or exist at the larger watershed or regional scale. Such issues or problems are most efficiently addressed by using a multi-collaborative approach [7].

Watershed studies provide the needed context to integrate the spatial and temporal complexities that arise 
when assessing the interactions of land management practices across a complex physical and biological landscape. Accordingly, Turkey Creek watershed (WS 78) was instrumented for gauging in late 1963 and monitored until 1984 [27] on the Santee Experimental Forest to provide the basis for eco-hydrological monitoring and modeling studies within this predominantly forested $3^{\text {rd }}$ order coastal watershed within the Francis-Marion National Forest in South Carolina, USA (Figure 1) [26]. This region is characterized by its rapidly growing population and associated residential and commercial development, and a forest resource base that supports both commercial values in terms of the wood products industry and societal values (e.g., example water supply, cultural history, scenery, and recreational activities). The most effective way to address these issues is through multi-cooperation among various disciplines and agencies for conducting long-term monitoring and modeling studies [7]. Therefore, recognizing the importance of long-term data from a relatively undisturbed large forested landscape in a rapidly changing coastal environment, the hydrologic monitoring was reactivated in 2005 by United States Department of Agriculture (USDA) Forest Service (http://www.srs.fs.usda.gov/charleston/) by installing a flow gauging station approximately $200 \mathrm{~m}$ upstream of the previous gauging station in collaboration with the College of Charleston and the United States Geological Survey (USGS).

The goal of this multi-collaborative approach was to transfer sound science-based information and provide a basis for continuing and expanded interdisciplinary research to address critical issues surrounding the sustainable management of present and future water resources on the low-gradient forested landscape of the southeastern Coastal Plain region, as was synthesized recently by [7] for research studies conducted in last 10 years. The

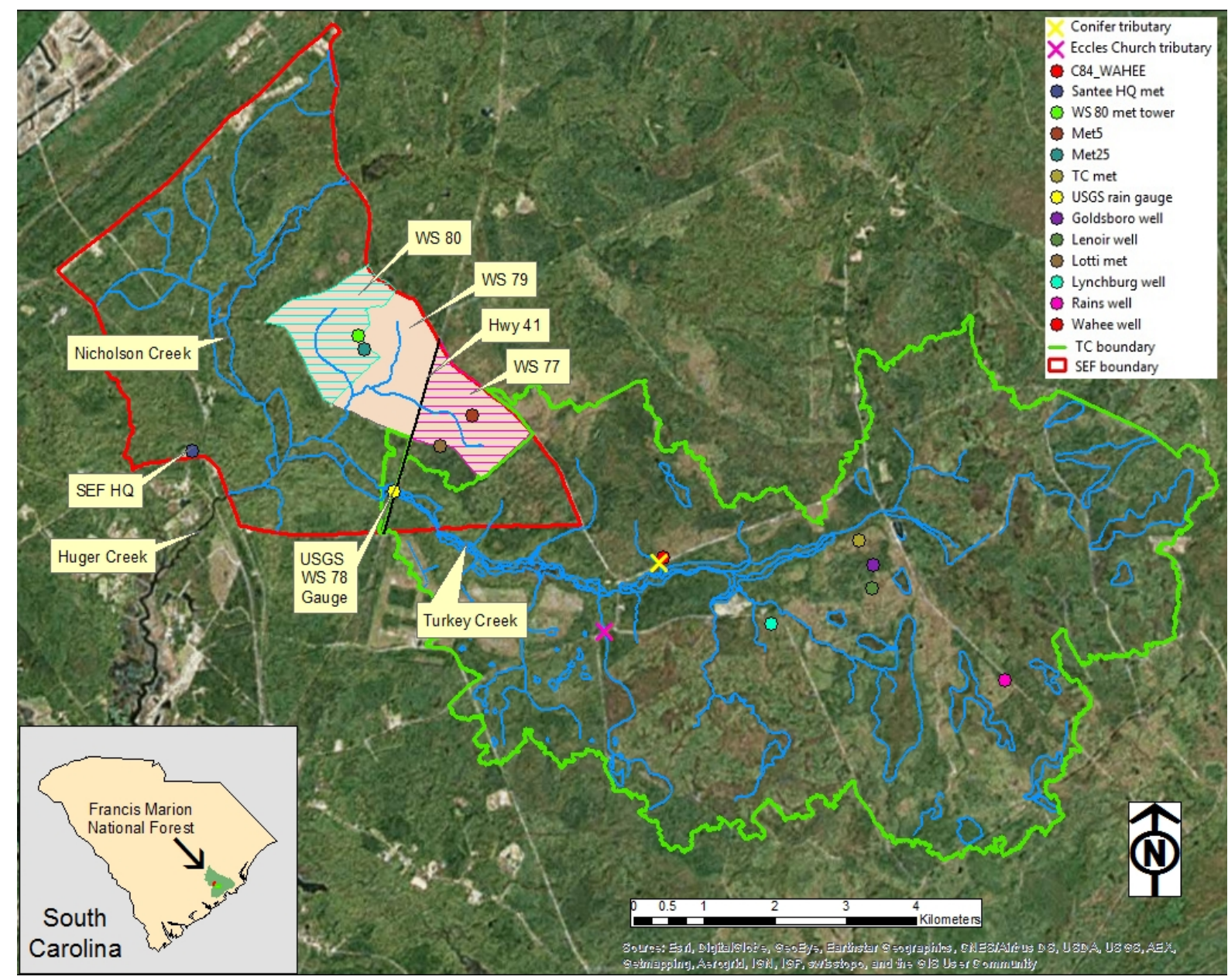

Figure 1. Location map of Turkey Creek watershed (WS 78) in green boundary using high resolution LiDAR data in 2011 (Table 1). Blue lines are streams and wetlands based on National Hydrography Data (NHD). Locations of weather stations, stream gauges, and ground water wells are also shown including for three other adjacent $1^{\text {st }}$ (WS77 and WS80) and $2^{\text {nd }}$ (WS 79) order watersheds within Santee Experimental Forest shown in red boundary. 
main objective of this paper is to document the ecohydrologic characteristics and identify and discuss elements of watershed management including water resources knowledge and assessment and modeling integrated water resources management by providing science-based applications and tools, administrative policy and decision process, and socio-economics as related to water resources management on this pilot watershed.

The scale of the entire Turkey Creek watershed (not shown) with the $6^{\text {th }}$ level 12-digit Hydrologic Unit Code (HUC) of $40-160 \mathrm{~km}^{2}$ drainage area is an intermediate one for analysis of watershed conditions but large enough to have many of the hydrologic complexities suggested and be addressed at national forest planning scales, but small enough to be effectively evaluated, managed and addressed at larger project and watershed improvement scales [28] [29].

\section{Watershed Description}

As currently defined the $3^{\text {rd }}$ order (1:24,000 scale) system at the gauging station, "Turkey Creek" (WS 78) is located within the USGS quadrangle maps of Huger (NE), Bethera (SE), Shulerville (SW and SE), and Ocean Bay (NW and NE) at $33^{\circ} 08^{\prime} \mathrm{N}$ latitude and $79^{\circ} 47^{\prime} \mathrm{W}$ longitude (approximate coordinate ranges of 610,400 to 628,600 easting and 3,658,500 to 3,670,500 northing [30]) in Berkeley County about $60 \mathrm{~km}$ northeast of the City of Charleston, South Carolina (SC), USA (Figure 1). Located within a $4^{\text {th }}$ level 8-digit hydrologic unit code (HUC 03050201) of the Cooper River sub-basin [28], watershed WS 78 is at the headwaters of East Cooper River, a major tributary of the Cooper River draining to the Charleston Harbor System [31]. WS 78 is typical of other similar relatively undisturbed forested watersheds in the South Atlantic Coastal Plain that is facing rapid urban development. The drainage area of the watershed in this low-gradient landscape apparently evolved within the range of 3240 ha in 1964 when it was identified for the study to 7260 ha [15] [18] [30] [32]. Even with considerable attention, hydrologic boundaries within coastal areas may need review [33]. Most recently after the acquisition of high resolution LiDAR data its recomputed drainage area with consideration of boundary road cross-drainage culverts based on extensive field survey stands at 5240 ha [34]. Without considering those culverts and extent of ditching, the calculated area was 5985 ha as posted by the USGS at its gauging site information page (http://waterdata.usgs.gov/sc/nwis/uv?site_no=02172035). Much of these data have been further refined with improved stream gauging, soil, ecological and surface detail maps with increasing use of the LiDAR and high definition aerial photography in their development for more detail and precision. For example, newly acquired LiDAR data is being used to enhance the ecohydrologic mapping of the National Forest including the study site. Application of the absorption of the LiDAR pulses in water provides linear context for determining likely stream pathways and water extent that is further checked with the high resolution aerial photography (NAIP 2013 Imagery). LiDAR derived DEMs and shaded relief of added detail are helpful in defining watershed boundaries and linear features such as drainage ditches, old roads, dikes and water diversions [33]. Similarly, [35] divided groundwater aquifers into more units providing different naming conventions to them compared to the older documents. On the gauging side, two more continuous flow monitoring stations have recently been added in east (Eccles Road) and west (Conifer Road) tributaries of the study watershed (Figure 1).

The topographic elevation of the watershed varies from approximately $2 \mathrm{~m}$ at the stream gauging station to 14 $\mathrm{m}$ above mean sea level (amsl). The humid, sub-tropical climate is characteristic of the coastal plain having well distributed rainfall, hot and humid summers, moderate winter seasons, and exposure to coastal wind to hurricane events. Accordingly, the average annual air temperature and precipitation, based on a 63-year (1946-2008) record at the adjacent Santee Experimental Forest was recorded as $18.3^{\circ} \mathrm{C}$ and $1370 \mathrm{~mm}$, respectively [3]. Seasonally, the winter is generally wet with low-intensity, long-duration (multiple-hour) rain events and the summer is characterized by high-intensity, short-duration ( $<1$ - 4 hour) storm events; tropical depression storms are not uncommon [17].

Land use within the watershed is comprised of 44\% (2306 ha) pine forest (mostly regenerated loblolly (Pinus taeda L.) and longleaf pine (Pinus palustris)), 35\% (1834 ha) in thinned loblolly and longleaf pine forest, 8\% (419 ha) mixed forest, 10\% (524 ha) forested wetlands and water, and 3\% (157 ha) in agricultural lands, roads and open areas. The calculated areas are based on percentage data [30] [32] and the total new drainage area of 5240 ha [34]. The watershed was heavily impacted by Hurricane Hugo in September, 1989, and the pine forest canopy was almost completely destroyed [36] while bottomland forests were relatively less impacted in the Category 4 winds. Most of the current forest stands on the watershed are approximately 25 years old with a mixture of remnant of large trees and natural regeneration. 


\subsection{Water Demand Management}

There are not any publicized issues of water demand management (e.g. improved efficiency of water usage, recycling/reuse of water, improved efficiency of water supply etc.), given that in this watershed the few houses and the small agricultural areas depend upon groundwater. However, there remains substantial uncertainty relative to the effects of the past natural and anthropogenic drainage modifications and their influence on hydroperiod, flow permanence, and even the extent of past activities relative to watershed boundaries. We know that drought is a contributing factor, but we do not fully understand why over the past decade, a watershed with 52 $\mathrm{km}^{2}$ goes dry about $30 \%$ of the time when it should be able to maintain perennial flow.

\subsection{Water Resource Assessment on Regional Level}

The regional water resources assessment looks both at surface and groundwater, including identification of the pertinent parameters of the hydrological cycle. The South Carolina State Water Assessment provides an overview of the State's surface and groundwater resources and includes information on the quantity, quality, availability and use of water in the State [37]. The assessment also describes existing water laws and regulatory programs, factors affecting surface-water availability and quality, and the State's ground-water distribution, well yields and chemistry. Conflicts in water availability stemming from the droughts of 1998-2002 and 2007-2008 are also summarized. The South Carolina Department of Natural Resources (SC DNR) is in the process of developing regional water plans for each of the State's eight major river basins that will be integrated into a composite state water plan (S. Harder, personal communication, 2015). This work includes the development of surface-water assessment models that will be used to evaluate the current and future availability of water in each basin as well as to test new water management strategies. The surface-water models are scheduled to be completed by the fall of 2016. Groundwater wise, regional groundwater levels have been historically reduced due to past withdrawals within the coastal areas. The withdrawals have lowered the hydrologic head that forces groundwater pressure and rate of flow within the aquifer, to streams and also riparian areas and wetlands. Anthropogenic "water uses" have also reduced levels of stored groundwater causing a predicted decline in streamflow (baseflow) [35] [38].

Detailed information on a regional assessment of the water resources of the South Carolina Coastal Plain and the Cooper River Basin where the study watershed (WS78) lies in the headwaters of East Branch of the Cooper River can be found in the water assessment report by the South Carolina Department of Natural Resources [37].

\section{Water Resources Knowledge Base}

\subsection{Physical Data}

The Lower Coastal Plain, where the study site is located, has a depositional topography caused by transgressions of the Atlantic Ocean with Pleistocene-aged sediments comprising the oldest exposures [39]. The regional remnants of sea level rise and fall are a series of beach terraces and back-barrier lagoonal sequences that roughly parallel the modern coastline. The geologically young topography of the Lower Coastal Plain is signified by shallow river valleys for streams originating within the Coastal Plain. We infer that in past times of lower sea level, these stream systems may have been more significant in their erosive power, which is relatively low at present.

Turkey Creek lies within the Talbot Marine terrace (also called Ten Mile Hill beds in some literature) which trends northeast to southwest, bounded on the northwest by the Bethera scarp and southeast by the more recent Suffolk scarp [5]. These landforms are often substantial determinants of hydrologic boundaries, but the marine and riverine erosion, as well as, in some instances, anthropogenic actions can modify hydrologic pattern and can alter coastal plain hydrology. Figure 2 shows a break in the Suffolk scarp (brown to yellow) that resulted in drainage (light blue) from the Talbot terrace (Turkey Creek headwater vicinity in green and within the Cooper River system) into the somewhat lower Pamlico terrace and headwaters of Wambaw Creek (blue) that ultimately drains northeast into the Santee River system [33].

Through analysis of an online map [40], the dominant soil series on the watershed are poorly drained Wahee (clayey, mixed, thermic Aeric Ochraquults), and Lenoir (clayey, mixed, thermic Aeric Paleaquults) series [32] [41]. The watershed also contains small areas of somewhat poorly and moderately well drained sandy and loamy soils such as Lynchburg (thermic Aeric Paleaquults), Goldsboro (thermic Aquic Paleudults), and Rains (thermic 


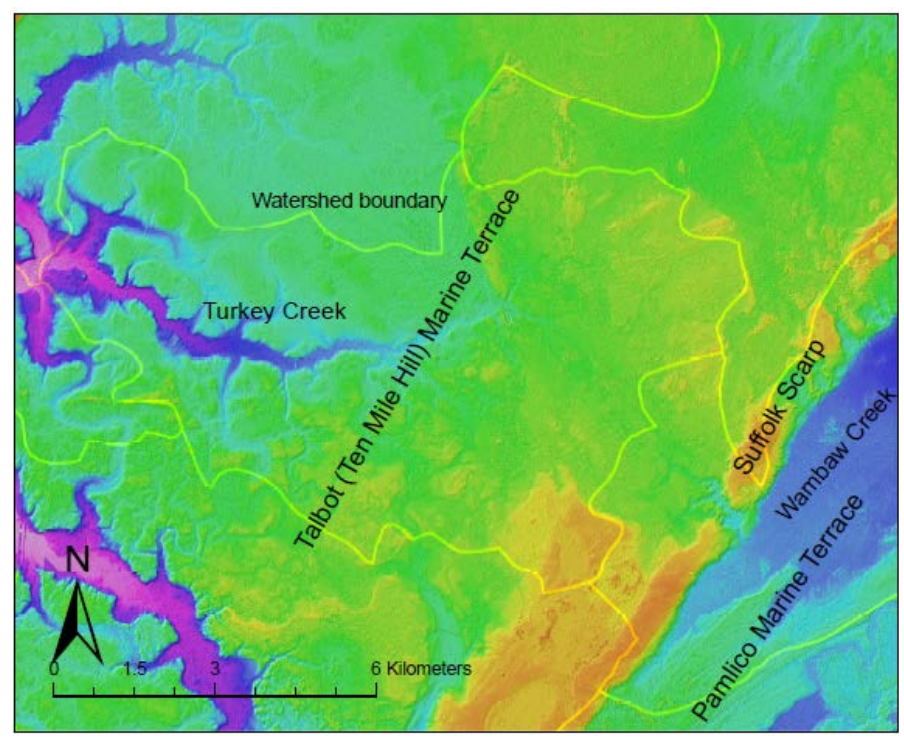

Figure 2. LiDAR DEM shaded relief image (1 - $16 \mathrm{~m}$ ) showing Talbot and Pamlico Marine Terraces with break in Suffolk Scarp and 2005 USGS WBD estimated boundary which separated Turkey Creek watershed which contains WS78 gauging station in Figure $\mathbf{1}$ and Wambaw Creek watershed.

Typic Paleaquults). Soils in the streambed and riparian buffers are comprised of the Meggett series (thermic Typic Albaqualfs). The right bank or northern half of the watershed contains sandy clay loams and silt loams, while the left bank or southern half is dominated by sandy clay loams. The permeability of these soils ranges from slow to rapid [40]. Overall, these soils have low infiltration capacity and high surface runoff.

\subsection{Hydrological Data}

Annual precipitation recorded during 1946-2008 period at the adjacent Santee Experimental Forest varied between $835 \mathrm{~mm}$ in 1954 to and $2026 \mathrm{~mm}$ in 1994 with an annual average of $1370 \mathrm{~mm}$ [3]. The minimum and maximum temperatures observed within the same period were $-8.5^{\circ} \mathrm{C}$ and $37.7^{\circ} \mathrm{C}$, respectively, with a daily average of $18.3^{\circ} \mathrm{C}$. The 63-year (1946-2008) annual potential evapotranspiration (PET) estimated using the Hargreaves-Samani method [42] adjusted with monthly factors based on Penman-Monteith [43] ranged between 970 $\mathrm{mm}$ to $1304 \mathrm{~mm}$, with an average of $1136 \mathrm{~mm}$ [3]. Thus the site has generally excess moisture as the average annual rainfall exceeds the average PET. However, records of hydro-meteorologic measurements (precipitation and streamflow) on the WS 78 exist only from 1964 to 1981 and again from 2005 onwards as described earlier. Studies conducted using the pre-Hugo data for (1964-1976) and post-Hugo data (2005-2014) are summarized below.

In a comparison of 5-year pre-Hugo daily flows of this study watershed (WS 78) with that from the adjacent $1^{\text {st }}$ (WS 80) and $2^{\text {nd }}$ (WS 79) order watersheds (Figure 1), it was hypothesized [44] that somewhat higher annual water yields from the largest WS 78 was possibly due to a difference in their land use, soils, and topography, increased base flows as well as potential discrepancies in drainage area calculation for flow estimate of WS 78 [34]. Using 13 years (1964-1976) of data, a large seasonal variability in storm event runoff coefficient (ROC) with higher values for the wet period than for the dry was found [18], potentially due to differences in forest ET that affected seasonal soil moisture conditions. This seasonal variability and evidence of ET influence has been further documented with more recent data sets from the first-order watershed WS 80 [12] demonstrating consistent results between studies. A recent hydrologic study [15] showed that the regenerated forest stand on the study watershed may be resilient to the natural disturbance such as Hugo in 1989 as indicated by the limited 4-year data of the measured stream flow response, compared to their expected values had the hurricane not damaged the forest. The spatially distributed hydrologic model Soil and Water Assessment Tool (SWAT) [45] was calibrated and validated to simulate daily and annual stream flow on this watershed [30], and that model is now being used to assess the future impacts of climate change on this landscape using scenario analyses. 
Figure 3 shows the comparison of daily flow duration curves for a 10-year (1965-1974) period before Hurricane Hugo (1989) and a recent 10-year (2005-2014) period since regeneration of forest stands 15 years after Hugo. The smaller plot in the upper right hand corner is the blown up for $1 \%$ to $100 \%$ time a given flow exceeds. Data showed that the daily flow occurred about $73 \%$ of the time for the pre-Hugo period versus $67.5 \%$ of the time in the post-Hugo period. Clearly, flows of $2.5 \mathrm{~mm}^{\text {day }}{ }^{-1}$ or higher (occurring $<8 \%$ of the time) occurred more frequently in the post-Hugo period than the pre-Hugo, with the highest daily flow of $91.2 \mathrm{~mm}$ on October 24, 2008 as a result of over $150 \mathrm{~mm}$ rain in 24 hours in already wet antecedent condition. This trend is consistent with other regional studies reporting potentially higher more intensive storms and peak flows as a result of changing climate [3] [46]. The frequency of smaller flows below $2.5 \mathrm{~mm}^{\text {day }}{ }^{-1}$ (occurring more than 91\% of time) was lower for the post-Hugo than for the pre-Hugo period, resulting in its lower total and average flow as will be shown below, potentially due to increased ET of the dense longleaf and loblolly pine stands regenerated after Hugo in 1989.

The peak flow rates for 100-, 50-, 25-, 10-, and 5-year return periods were computed by using Pearson III-type distribution in the flood frequency analysis with 13 years (1964-76) of pre-Hugo peak flows are shown in Table 1 [44]. These results seem to be in reasonable agreement within the standard errors, except for the 50and 100 -yr periods with underpredictions as much as by $29 \%$, compared to the results obtained for this study watershed using the USGS regional formulae [47] for rural coastal basins developed using data from South Carolina, North Carolina, and Georgia because of its location in rural areas of the South Carolina Coastal Plain.

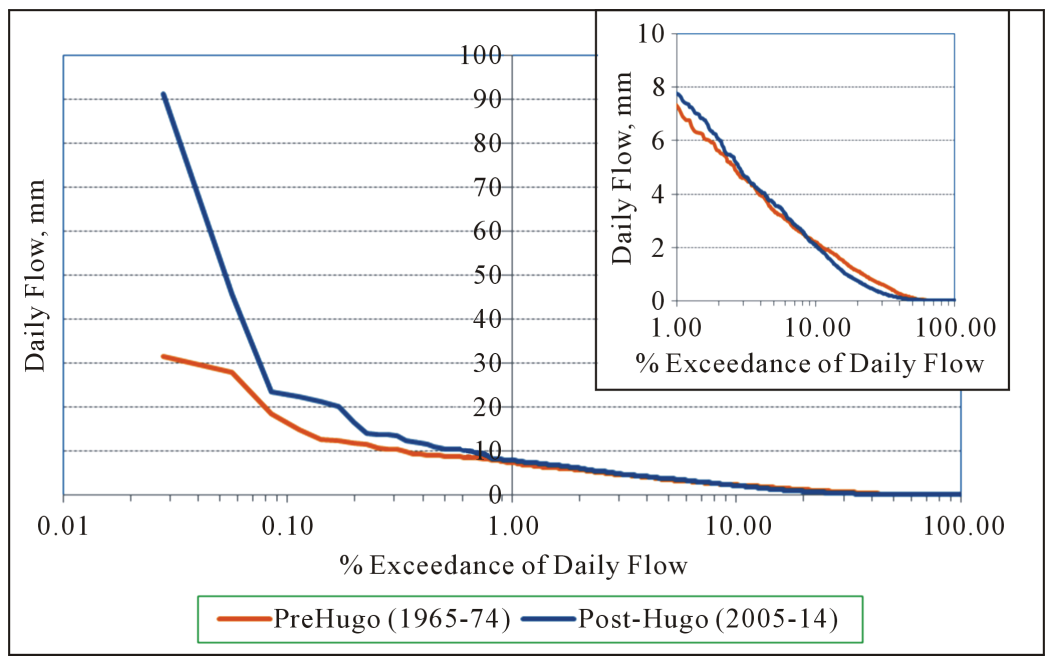

Figure 3. Measured daily flow duration curves for the 1965-1974 (pre-Hugo) and 2005-2014 (post-Hugo) periods for the study watershed.

Table 1. Estimated peak discharges (Q) and maximum discharges [47] predicted by Pearson Type-III (with a standard error in parentheses) and minimum discharges predicted by Gumbel distribution for various years of return periods for Turkey Creek watershed (WS 78).

\begin{tabular}{|c|c|c|c|c|c|c|c|}
\hline Return period (year) & 2 & 5 & 10 & 25 & 50 & 100 & 500 \\
\hline Peak flow formula [47] & $\begin{array}{c}\mathrm{Q}_{2}= \\
60.3 \mathrm{~A}^{0.649}\end{array}$ & $\begin{array}{c}\mathrm{Q}_{5}= \\
123 \mathrm{~A}^{0.627}\end{array}$ & $\begin{array}{c}\mathrm{Q}_{10}= \\
174 \mathrm{~A}^{0.617}\end{array}$ & $\begin{array}{c}\mathrm{Q}_{25}= \\
245 \mathrm{~A}^{0.606}\end{array}$ & $\begin{array}{c}\mathrm{Q}_{50}= \\
309 \mathrm{~A}^{0.600}\end{array}$ & $\begin{array}{c}\mathrm{Q}_{100}= \\
380 \mathrm{~A}^{0.594}\end{array}$ & $\begin{array}{c}\mathrm{Q}_{500}= \\
550 \mathrm{~A}^{0.583}\end{array}$ \\
\hline $\mathrm{Q}\left(\mathrm{m}^{3} \mathrm{~s}^{-1}\right)$ & 12.0 & 22.9 & 31.5 & 42.9 & 53.2 & 64.2 & 76.9 \\
\hline $\begin{array}{c}\text { Maximum discharge } \mathrm{m}^{3} \mathrm{~s}^{-1} \\
\text { by Pearson type-III } \\
(1965-1976)\end{array}$ & $15.9( \pm 3.2)$ & $25.1( \pm 3.9)$ & $30.6( \pm 5.1)$ & $37.0( \pm 7.4)$ & $41.5( \pm 9.5)$ & $45.7( \pm 11.8)$ & \\
\hline $\begin{array}{l}\text { Minimum discharge } \mathrm{m}^{3} \mathrm{~s}^{-1} \\
\text { by Gumbel distribution }\end{array}$ & 0.035 & 0.031 & 0.026 & 0.021 & 0.017 & 0.010 & \\
\hline
\end{tabular}


However, it is important to acknowledge some uncertainty in this comparison because the estimates are from regionalized regression equations [47] with estimated error of 34\% - 47.7\%, depending on the percent chance exceedance event, and also did not use the peaks flows from this Turkey Creek watershed. Although both the methods used the Pearson III-type distribution, one reason for higher predictions by the USGS method was due to use of data from some rural basins with less than $10 \%$ urban areas in their regression models and also possibly due to the use of a generalized regional skew factor of -0.019 . The results, except for the $40-\mathrm{yr}$ and 100 -yr periods, are comparable given the above reported range of average error predictions [47]. The limitation in estimates from the flood frequency formula should also be acknowledged as shown by [48] whose analysis shows a potential of $18 \%$ and $48 \%$ standard errors of estimates of mean annual discharge and a flood of 50-yr return period, respectively for this the 13 -year period analyzed here.

The 100- and 50-year peak flow rates of 58.0, and $48.1 \mathrm{~m}^{3} \cdot \mathrm{s}^{-1}$, respectively, estimated by the South Carolina Department of Transportation (C. Bodiford, personal communication, 2004) for their design of the highway bridge at the Turkey Creek gauge were $27 \%$ and $13.7 \%$, respectively, higher on the conservative side than the Pearson III-type results (Table 1). At the same time the Gumbel distribution-also referred to as Fisher-Tippett Type I-was used to predict minimum discharges for 2- to 100-yr return periods for the Turkey Creek watershed in Table 1 [44]. The predicted maximum and minimum flow values varied within about three-fold for 2- to 100 -yr period. Although these high and low flow frequency discharge information are useful for stormwater management planning and design including environmental flow requirements for ecosystem restoration [49], the predictions developed using only 13 years of historic data need to be cautiously interpreted and re-evaluated using longer periods of observed data for more accurate predictions. Furthermore, although the study watershed went dry (zero flows as measured by the deployed sensor) about $1 / 3$ of the time (mostly summer) for the recent post-Hugo period (Figure 3), very small flows difficult to be detected by the sensor may still possibly be occurring in the hyporheic zone of the stream bed.

The annual rainfall, streamflow, and runoff coefficient (ROC) for the 1964-1976 pre-Hugo and 2005-2014 post-Hugo periods are shown in Figure 4 and Figure 5, respectively for this predominantly forested watershed.

The average annual rainfall of $1306 \mathrm{~mm}$ for the post-Hugo period was only 1\% lower than the pre-Hugo period. However, the average annual outflow of $247 \mathrm{~mm}$ in the post-Hugo period was about 20\% lower than that for the pre-Hugo period, likely due to increased ET as a result of increased temperature in the region [3] and regenerated pine stands. This flow pattern was evident also from the flow duration analysis presented above where the pre-Hugo frequency of flows $<2.5 \mathrm{~mm} \cdot \mathrm{d}^{-1}$ occurring $>91 \%$ of time was higher for the post-Hugo period. The post-Hugo mean annual runoff coefficient of 0.18 was significantly $(\alpha=0.05)$ lower than that $(0.23)$ obtained for pre-Hugo period, potentially due to relatively drier years with higher potential evapotranspiration (PET) [50] resulting in much reduced flows in 2011 and 2012. The seasonal streamflow dynamics of the watershed is much dependent upon the antecedent conditions defined by the water table position or initial flow rate with generally lower flows during the summer growing season with high ET demands compared to the wet winter periods with high water tables as shown in related studies [12] [18] [51].

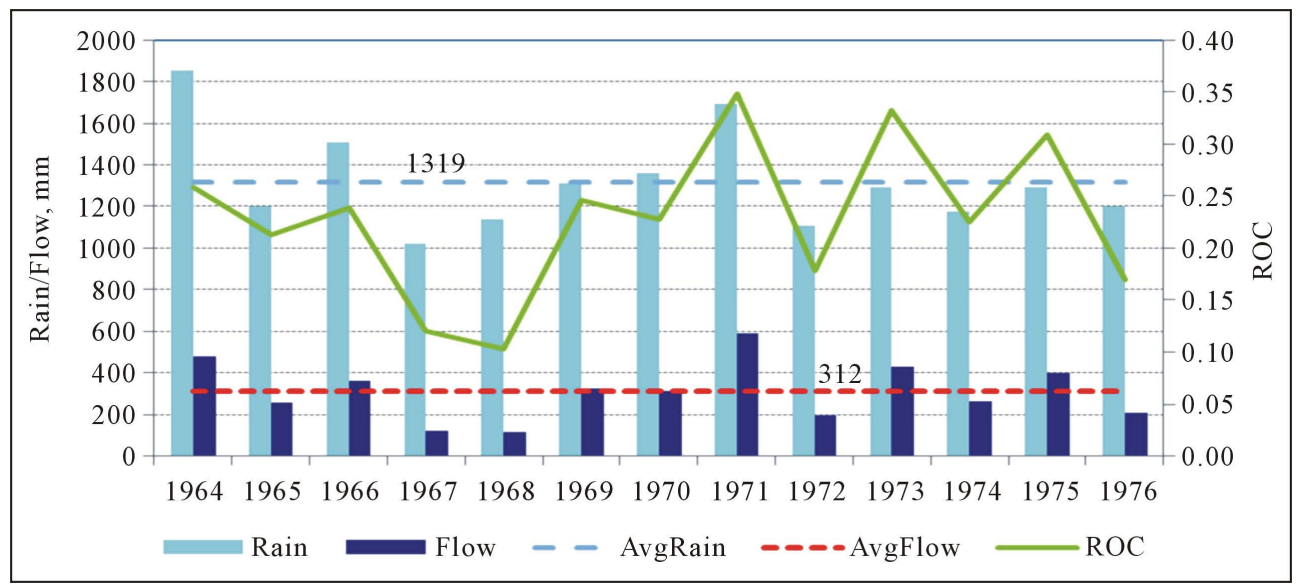

Figure 4. Annual precipitation, stream flow and runoff coefficient (ROC) for 13 years (1964-1976) pre-Hugo period. 


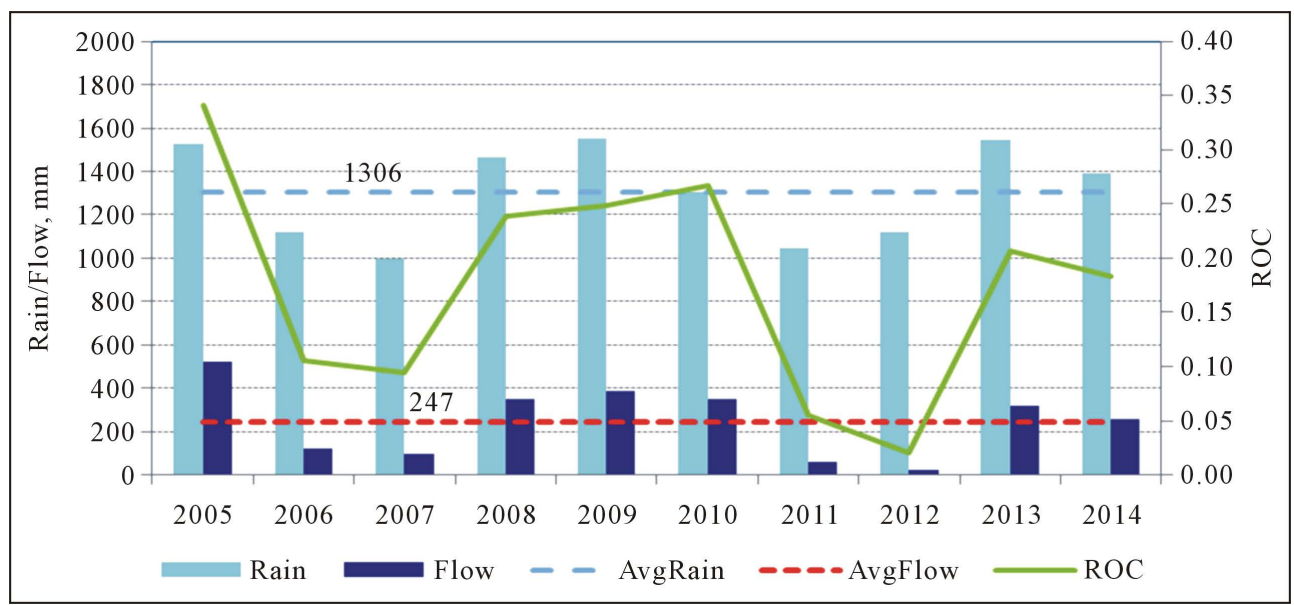

Figure 5. Annual precipitation, stream flow and runoff coefficient (ROC) for 10 years (2005-2014) post-Hugo period.

Using the 13 years of historic data the average annual water yield was $312 \mathrm{~mm}$, which is equivalent to $16.35 \times$ $10^{6} \mathrm{~m}^{3}$. On an average annual basis, evapotranspiration (ET), calculated as the difference in precipitation and stream outflow, was estimated to be $1008 \mathrm{~mm}$ (after adjusting flow for drainage area in [27]), which is $11 \%$ less than the estimated PET of 1135 mm using Hargreaves-Samani-based PET corrected for monthly adjustments [3]. However, the average annual water yield for the last 10-years (2005-2014) was calculated to be only $12.9435 \times$ $10^{6} \mathrm{~m}^{3}$, a reduction in $20 \%$ compared to the pre-Hugo estimate. The 10-year data indicate that the average annual water yield of this watershed may possibly be in decline. With respect to extractions of surface water for drinking water supply or irrigation, there aren't any records and it is unlikely that surface water is being used for these purposes. The extent and continuing function of hydrologic modifications have not been addressed and may be contributing to increased peak flows and reduced baseflows.

Hydrology of this forested watershed is complex due to the low-gradient stream network and wide riparian floodplain or linear depressions in the landscape that may flood, but not necessarily from overbank flow. Accurate measurement of stream discharge for extremely large events is complicated by shallow flooding across large areas with variable roughness and braiding of channels. Furthermore, the existence of weakly to strongly connecting wetland swamps, swamp streams and riparian floodplains along streams makes the interaction of surface and subsurface water even more complicated because of their dominance within the landscape as well as spatial and temporal variability within the watershed [52] and considering groundwater-surface water interactions in wetlands for integrated water resources management [53]. Difficulty in accurate estimation of watershed boundary in this low-gradient system also poses challenges in estimation of depth-based watershed stream outflows, nutrient exports, and in design of engineering structures.

\subsection{Hydrogeology and Groundwater Resource Data}

The USGS has compiled a national atlas of groundwater in the United States and published detailed regional studies of all major aquifers, including the Southeast US [35]. Also, the state agency South Carolina Department of Natural Resources, within their Land, Water and Conservation Division, monitors the deeper confined aquifers in the Coastal Plain region [54] [55]. As stated above in the Physical Data Section, there are now updated geological information for sediments comprising the shallow sediments nominally referred to as the surficial aquifer in the coastal plain in South Carolina [5]. Some local shallow wells were used to perform slug and bail tests using the volume displacement method [56] [57]; the hydraulic conductivity of the surficial aquifer in the northwestern area of Turkey Creek watershed is about $1 \times 10^{-6} \mathrm{~m} \cdot \mathrm{s}^{-1}$ for the silt loams of the Craven series and $4 \times 10^{-6} \mathrm{~m} \cdot \mathrm{s}^{-1}$ for the sandy clay loams of the Wahee series.

Except for shallow water-supply wells in the surficial unconfined sediments, which typically produce less than 100 liters per minute, the main groundwater resource for individuals and perhaps smaller communities in Berkeley County is the Santee Limestone, an Eocene-aged, semi-consolidated silty limestone and part of the same lower Floridan aquifer system that is an important groundwater resource in coastal Georgia and in Florida 
[58]. However, urbanizing areas have transitioned to surface water sources to avoid further drawdown of groundwater levels and the potential for salt water intrusion into fresh groundwaters. The Floridan/Santee aquifer is partially-confined beneath the Turkey Creek watershed, where the top of the Santee Limestone is approximately $20 \mathrm{~m}$ below ground surface (bgs) in the western side of the watershed and about $13 \mathrm{~m}$ bgs in the eastern area, and further east at the Santee River, the eastern boundary of FMNF, it is close to or at ground surface. Although not directly measured at the Turkey Creek area, the depth ranges in thickness from 60 - $120 \mathrm{~m}$ [59]. In the western area the Santee Limestone is overlain by about $10 \mathrm{~m}$ of dense, semi-consolidated calcilutite known as the Parkers Ferry Formation of late Eocene age [60]. Initial groundwater data at the site suggest this unit acts as a confining layer to groundwater flow between the shallow surficial sediments and the deeper Santee Limestone. However, it is not present in the eastern area of the Turkey Creek watershed, where fine-grained sands of the Pleistocene-aged Ten Mile Hill (Talbot) beds overlay the Santee Limestone [60]. An ongoing study analyzing hydrographs of hydraulic head in water-table wells and piezometers, using data collected continuously since February 2006 has focused on groundwater recharge in this watershed and baseflow in Turkey Creek to understand the role of shallow groundwater on stream flow behavior [11].

\subsection{Water Quality Data}

No water quality data were available on the study watershed for the pre-Hugo 1964-1976 period. However, in 2001 water samples were collected from a section of the stream about one $\mathrm{km}$ upstream of the current gauging station on Turkey Creek as one of the three locations in Francis Marion National Forest to examine several water quality parameters, including fecal coliform, dissolved oxygen (DO), conductivity (total dissolved solids), mercury and salinity. Sampling was conducted to ensure that forest streams, lakes, wetlands, and riparian areas are healthy, functioning ecosystems that produce sustained flows of high quality water and to provide a reference for future planning purposes [61]. The results from September 2001 to January 2002 indicated that the Turkey Creek stream water was impaired for fecal coliform bacteria (100 colonies per $100 \mathrm{ml})$.

Electrical conductivity remained relatively stable $\left(<200 \mu \mathrm{S} \cdot \mathrm{cm}^{-1}\right)$ through the measurement period (JuneAugust, 2001). Turkey Creek was repeatedly found to have dissolved oxygen (DO) values of less than the threshold value of $5 \mathrm{mg} \cdot \mathrm{l}^{-1}$ during the summer of 2001. In terms of salinity, Turkey Creek near the old gauge (about $200 \mathrm{~m}$ downstream of the current gauge) maintained a salinity level of $0.1 \mathrm{ppt}$ throughout the sampling period of June-August, 2001, indicating that there is no tidal influence. Because of the heightened concern over the amount of mercury (Hg) and methylmercury in coastal waters, Turkey Creek was also tested for total $\mathrm{Hg}$ and methyl-Hg concentrations [61]. The concentrations of Total Hg and methyl Hg in waters of Turkey Creek were 3.2 and $0.34 \mathrm{ng} \cdot \mathrm{l}^{-1}$. Total Hg concentrations in water and mud provide some measure of the potential for contamination. The authors reported that because of the proximity of the National Forest that contains Turkey Creek to other known areas of mercury contamination and the abundance of wetlands within the National Forest, some caution should be taken when regularly consuming fish on or adjacent to National Forest land, and particularly those species of fish that are carnivorous, such as bowfin, large-mouth bass and black crappie.

The high stream water temperatures recorded in the summer were consistent with the estimated high PET for relatively dry months. As expected, the DO concentrations showed an inverse relationship with the water temperature with high values during the cold winter and lower values during the hot summer months, with an average of $6.1 \mathrm{mg} \cdot \mathrm{L}^{-1}$, consistent with previous findings [61]. The $\mathrm{pH}$ values ranged from 5.4 to 8.8 with an average of 7.1 for 2006-2009 with a no definitive pattern [15]. The annual mean $\mathrm{pH}$ of all watersheds significantly increased with stream conductivity $(\mathrm{p}<0.05)$. Most of the nitrogen $(\mathrm{N})$ component was dominated by the organic N (ON). Phosphate concentration showed a systematic decreasing trend from 2006 to 2012 [62]. Nitrogen and phosphate concentrations varied with amount of rain received with years receiving highest rainfall registering lower concentrations, possibly due to dilution effects. Data of nutrient concentration measured on this watershed are shown to be within the ranges for similar land use of the coastal plain, except for $\mathrm{NH}_{4}-\mathrm{N}$, which was slightly higher. A detailed analysis of stream water chemistry is still underway. These data may be useful as a reference for comparison with more developed watersheds in the region.

\subsection{Socio-Economic Data}

There are no specific socio-economic data for the Turkey Creek watershed. Socioeconomic information was derived from data for Berkeley County where this watershed is located, with primary employment in fisheries, fo- 
restry, and agriculture. The secondary employment in the region is in agro-industry and energy. Potential tertiary services may include construction, commerce and civil employment. According to the US Census Bureau [63], $66.5 \%$ of the population 16 years and older are in the labor force, of which $3.2 \%$ are employed in the Armed Services. The unemployment rate for the county is $11.9 \%$. The employment distribution as a percentage of population is estimated at $31.0 \%$ in management, business, science, and arts; $25.5 \%$ in sales and office occupations; $17.1 \%$ in service occupations; $11.9 \%$ in natural resources, construction, and maintenance occupations; and the remainder in production, transportation, and material moving occupations. The main industries in Berkeley County include educational services, health care and social assistance (19.5\%); manufacturing (13.5\%); retail trade (11.8\%); and professional, scientific, management, and administrative services (11.8\%). Recent ongoing expansion of industrialized areas of the Greater Charleston into Berkeley County may influence the current employment statistics.

\subsection{Demographic Data}

The population and its growth rate for Berkeley County where the watershed is located are 177,845 and 9.1\% per decade, respectively, as per the 2010 census [63]. Unfortunately, the population data for the watershed is not available through the census, but this is a rural area dominated by $98 \%$ national forest ownership. We conducted a survey of the watershed in May 2006, which revealed 12 houses within the watershed. We estimate total number of 33 people based on average family size per household of 2.77 for Berkeley County in 2010, yielding a population density of 0.52 person $\cdot \mathrm{km}^{-2}$, which is considerably below the regional norm [63]. The life expectancy as a whole for South Carolina is 74.9 years and $80.2 \%$ of the population with 25 years of age and higher was found to have high school diplomas or hold higher degrees.

\subsection{Water Usage Data}

The households within the watershed use groundwater wells for drinking water. Water consumption per capita is estimated to be $300 \mathrm{l} \cdot \mathrm{day}^{-1}$ per person based on some unpublished data for rural communities in South Carolina [37]. All houses are equipped with septic tank systems for sewage disposal. The main source of past water supply using groundwater wells has moved in the direction of surface water sources with treatment due to lowering water tables and potential for salt water influx into fresh groundwater. Septic systems are often used in rural areas for the treatment of sewage, but the ability of many soils to provide ample filtering and percolation has been an issue. Community and urban water treatment systems are in most instances the new norm.

\subsection{Vegetation Data}

The vegetation on the watershed is mostly comprised of mixed pine-hardwood forests. The current forest stands in the watershed include loblolly pine (Pinus taeda L.), loblolly pine-hardwood, pond pine (Pinus serotina), pond pine-hardwood, longleaf pine (Pinus palustris P. Mill.), baldcypress (Taxodium distichum), yellow pine (Tamias amoenus), Southern oak (Quercus falcata)-yellow pine, bottomland hardwood-yellow pine, white oakred oak (Quercus falcate)-hickory, sweetgum (Liquidambar styraciflua L)-yellow poplar (Liriodendron tulipifera), sweet gum-oak-willow, baldcypress-water tupelo (Nyssa aquatica L.), sweet bay (Magnolia virginiana)swamp tupelo (Nyssa sylvatica)-red maple (Acer rubrum), and flatwoods-brush [32].

\section{Water Resource Assessment}

\subsection{Water Demand Assessment}

Since the population on the watershed is so small and depends primarily upon the groundwater wells, no assessment is available and substantial uncertainty exists about past hydrological modifications and their ongoing effects. Accordingly, the only source of withdrawal from the watershed is by forest/vegetation ET, which is estimated at $1030 \mathrm{~mm} \cdot \mathrm{yr}^{-1}$.

\subsection{Environmental Impact Assessment and Strategic Impact Assessment}

No environmental or strategic impact assessments have been conducted specifically for the watershed to date. However, environmental assessments for forest health and stream water quality have been conducted by the 
Forest Service for the whole Francis Marion National Forest, which includes the Turkey Creek watershed [61]. As stated in that report, the quality of stream water of Turkey Creek was reported as being impaired for coliform bacteria. The likely sources include wildlife, cattle and horses on the small farms, and septic systems. The invasive wild hogs are a growing coastal menace relative to their riparian and water quality impacts. However, there are no specific study data to document the extent or probable source areas. Another emerging issue is the methyl-Hg, and monitoring has recently been initiated. Currently the draft version of the environmental impact study (EIS) associated with the ongoing National Forest plan revision [64] suggests that Turkey Creek will be impacted more than other vicinity subwatersheds relative to timber thinning and harvesting that favors restoration of longleaf pine and prescribed fire where suitable within the urban interface. Turkey Creek may also be selected as a priority watershed where efforts to improve watershed condition and function will be increased.

\subsection{Social Impact Assessment}

No specific social impact assessment of management activities on the Turkey Creek watershed has been conducted to date. However, the public review process of forest management practices by the National Forest lands does include social and community considerations. There are also programs to increase the public awareness of prescribed fire and smoke management, restoration of native plant communities, and recreational uses of the forest. The National Forest has recently been recognized for the values it provides by the community leaders, reflecting the importance of forest lands for ecological, economic and cultural values.

\subsection{Risk or Vulnerability Assessment}

The South Carolina Department of Health and Environmental Control (SCDHEC), under regulation by the 1973 Federal Clean Water Act, posts a listing (called the 303 (d) list) of impaired water bodies that do not meet federal standards, lists the water bodies already impaired or at risk or vulnerable, and the activity restrictions. As mentioned earlier, Turkey Creek was listed under 2006303 (d) list for exceeded limits of fecal coliform. However, Turkey Creek is not on its current 2014 listing, so the impairment may have been temporary, based on circumstances that have been addressed. Water quality information mentioned above was reconnaissance level data [61]. Research studies suggest that there are very few water quality related issues, but periods of drought cause flow to stop with associated impacts to aquatic and riparian life. The current revitalization effort with multiple monitoring and modeling studies will provide a basis in the near future for a more detailed risk assessment of water quantity and quality. Estimated in the draft forest plan environmental analysis suggest existing activity within the watershed increase water yield by $8 \%$ and proposed activity within the next decade may increase water yield between $5 \%$ and $11 \%$, based primarily under low density forest management and prescribed fire [64]. These estimates will be compared with results from ongoing SWAT modeling assessment for various climate change scenarios at the study site.

\section{Integrated Water Resource Management (IWRM)}

\subsection{Issue Identification}

Many of the ecohydrologic and integrated water management issues on this freshwater system proposed/identified at earlier phase of the project have been addressed by collaborative approaches during last 10 years as reported recently [7]. For example, reports have been generated concerning issues on design peak and low flow discharges for various design storms and flow duration pattern including their scaling issues generally used in pre-development storm water management scenarios, design of cross-drainage structures, and allocation of environmental flows [44]; water budget components generally used in restoration and comparison with developed watersheds [3] [14] [15] [17] [30] [65]; storm event characterization in terms of their peak flow rates, time to peak, runoff volumes and duration, and runoff ratios also used in pre-development scenarios and design of the best management practices [12] [18] [51] [66]; and storm runoff generation process and contributions of the subsurface base flow and surface runoff in total stream yields needed for water management and estimating pollutant discharges [11] [12] [15] [17] [18] [51] [67]. A study on recharge rates into the underlying groundwater aquifer and its quality in this region was conducted [11], related publications on the interaction of precipitation, surface and groundwater flow and their relative contributions to stream flow dynamics in the riparian floodplain of this lowland forested watershed are also available [67]-[69]. 
The issue with resolution of available topographic maps and associated digital elevation models (DEMs) in delineating watershed boundary for the drainage area and estimating effective surface depressional storage representing heterogeneity in surface micro-topography on hydrologic functions were also studied [34] [70]-[72]. Issues related with effects of climate variability and potential climate change including extreme natural disturbance like Hurricane Hugo in 1989 on vegetation dynamics, long-term streamflow, ET, and nutrient exports of these watersheds have also been studied and reported [3] [14] [15] [73]-[76]. Many of those above studies provided data and information in terms of water resources management on the Turkey Creek watershed primarily based on characterizing the watershed as a baseline "reference" for inter-site comparisons, evaluating the impacts of other developing watersheds in the region, and designing the best management practices. However, there is some uncertainty with applying Turkey Creek as a reference stream that must be considered. Little is known with respect to the differences that exist relative to marine terraces and past hydrologic modifications. For example, substantial variability of drainage size exists in the NC coastal plain before developing intermittent or perennial streams [77]. Without substantial more information and field verification, our assumption must be that conditions are variable and continuing efforts will be needed to refine and clarify coastal plain hydrology. Streams within each geologic terrace may be affected differently, such as how deep erosion has entrenched into the marine terrace surface, or how deep restrictive layers are such as identified by shallow water tables from estuarine silt and clay deposits. There are too few long-term coastal stream gauging stations and ongoing research to know how far we have come, let alone how far we must go to understand coastal systems. The thought is that we do now know substantially more than we did thirty years, even 10 years ago. However, due to increasing urbanization and population growth near the coastal waters together with changing climate and sea level rise, newer emerging issues on storm water management, increased demand of water supply and quality, management for ecological restoration, and other associated ecosystem services will continue to be complex and a challenge to address. Therefore, additional science based collaborative research on integrated water management should continue to address such challenges including some of other key science questions related to this lowgradient coastal forest ecosystem listed below:

What are the uncertainties associated with current knowledge of surface and groundwater interactions and their partitioning that affect the key ecosystem services like water supply, water quality, and biogeochemical processes and transport in this coastal landscape? How will those uncertainties be addressed?

What is/are the cause(s) of the high methylization efficiency of $\mathrm{Hg}$ in these streams, and how do forest management practices affect $\mathrm{Hg}$ transport and methylization? How will the processes affect at this site compared to other studies?

How will a changing climate affect the hydrology (particularly streamflow and ET) and water quality of this forest ecosystem in next decades and what will be their implications to the current forest ecosystem? What are the spatial and temporal dynamics of ET as affected by various stand types on the watershed?

In what ways are the presence of the existing culverts and bridges and legacy water management structures influencing the runoff and its quality and pathways, peak discharges, timing and baseflow, especially in the face of changing climate where high intensity storm events are in forecast for the region? [78]

To what extent may the surface and groundwater hydrology and thus the riparian vegetation and aquatic habitat be influenced by potential sea level rise as a result of climate change?

What are the mechanisms and rates of feedback between topography, hydrology, ecology (vegetation), and geochemistry and how do these vary as a function of local climate? Are there threshold phenomena in these feedback mechanisms and can the mechanisms be quantified?

How does the interaction of tidal waves downstream of the Turkey Creek watershed, which discharges freshwater outflow to Huger Creek downstream, affect the eco-hydrological and biogeochemical processes including net primary productivity, carbon balance and greenhouse gas emissions in the tidal streams in the face of changing climate and sea level rise? [79]

How do we develop research techniques to minimize landscape scale eco-hydrological effects of forest management treatments like prescribed fire or biomass treatment, fuel hazard reduction generally applied for improving the forest health in this landscape?

\subsection{Defining Management Options-Scenarios}

The National Forest is revising the existing management plan for the forest. Within that context, forest roads, 
timber harvest, prescribed fire, sustaining habitats, hiking trails, streams, riparian buffers and wetlands are also included. The development of the forest plan considers management options, conservation needs and public use, with each option subject to public review. The plans are updated on approximately a 10-year basis, unless specific needs arise, situations change, or regulations are modified. Currently a new 10-year plan (2016-2026 or beyond) forest management draft is underway with inputs from the stakeholders. There are also supplemental assessments, which are specific to a particular use or management objective. For example, a special roads analysis [80] was prepared as a supplement to the Francis Marion National Forest Land and Resource Management Plan of 1996, to address the use and needs of forest roads. In the recently prepared draft, two key issues that are being addressed are: 1) to what extent and where should native ecological systems be restored? and 2) what is the best approach for dealing with the rapid change in land use and population growth? [64]. In that draft, Turkey Creek was identified as one of the priority watersheds for improving hydrologic functions based on historic past modifications as well as the rehabilitation of existing cross-drainage structures that affect wetland and riparian structure, biota, processes, and functions and restoring longleaf pine ecosystem together with its redcockaded woodpeckers habitat as an at-risk species. In making this consideration, it is likely to also be a center of forest management activity with extensive thinning and prescribed burning for forest health, support of ecological systems and to address forest health and fuel loading.

All management options include an array of forest management practices with varying intensities of stand tending including regeneration, thinning and whole-tree biomass removal or mulching (both understory and overstory). Removal of thinned biomass as a management treatment is undertaken primarily to reduce fire hazards and provide a green solution to augment burning fossil fuels. To a great extent—after Hurricane Hugothe forest has matured with commercial value too expensive to purchase and burn. However, understory biomass removal using mastication or prescribed burning may still be conducted for restoration of longleaf pine and in areas where burning fuels is unacceptable. Without fire disturbance, loblolly pine is the more competitive, faster growing species. Both species are facultative species that can be found in wetlands including wet pine sites. Longleaf pine favors prescribed burning and sustains ecosystems with higher ecological diversity and longevity, more resilient to disturbances such as those associated with climate change. Furthermore, restoration of longleaf pine ecosystems helps to restore the endangered, red-cockaded woodpecker (RCW) habitat. Following the stand tending operation, prescribed fire is conducted generally every two to three years to maintain a relatively low stocking level in the understory. Also, as the National Forest manages this public land for recreational purposes such as hiking, hunting, horse riding, fishing, bird-watching, canoeing, driving all-terrain vehicles (ATVs), management decisions are often taken in terms of keeping the trails and land safe and pleasant. Due to the sensitivity of some species, activities have to be constrained to limit their impact to only designated areas.

\subsection{Establishment of Decision Criteria: Constraints and Factors}

The USDA Forest Service is the decision maker for actions on its national forests. Those decisions are subject to local, state and federal laws and regulations, and there is coordination with state and federal agencies. There are numerous laws, executive orders and regulations that directly or indirectly address some aspect of water management on the National Forests [81]. Policy instruments for water quantity, quality, ecosystem habitat, and spatial planning are available for managing the water system and a variety of other resources. Similarly, the general public and stakeholders (landowners on the watershed) have collaborative roles within the environmental assessment, analysis and decision making process. The National Forest maintains technical staffing support to help prepare draft documents and line officers with designated authority within the agency review documents and make decisions.

The decision criteria for water resources management as such have not yet been formulated for this watershed to our knowledge. However, regardless of the decision, the alternatives suggest there will be some emphasis on managing and restoring forest species (particularly longleaf pine), wildlife habitat and increased considerations given to hydrologic modifications that may benefit water resources. For example, areas of thinning, longleaf conversion and prescribed burning in the watershed may reduce transpiration and increase soil saturation possibly resulting in increased water quantity (stream flow) and stream water nutrient concentrations on a short-term basis [14] [82]. The increasing emphasis on frequent prescribed burning to maintain woodland and savanna densities will not only help sensitive habitats, but also help to maintain water yield increases. One of the constraints for such large-scale activities is to protect water quality and improve aquatic habitats with the riparian manage- 
ment zone buffers while also considering activities to protect wetland and riparian functions outside of this zone. Prescribed fire may still occur within the riparian areas, but greater attention is made to allow the prescribed fire to back into riparian areas rather than direct lighting. A recent case is with the adjacent first-order watershed (WS 77) (Figure 1) where 84\% of the land had understory burning on May 10, 2003 leaving only the riparian buffers along the stream. Hardwood buffers along streams supply better food for aquatic organisms, and they also reduce fire frequency and intensity as compared to pine trees. Burning may also be limited near the urban interface near Highway 41, the downstream boundary of the gauged watershed. The prescribed burning is becoming a larger issue as the urbanization of Charleston has been expanding and the watershed as well as most of the National Forest is located near or within the wildland-urban interface (WUI).

Any new activities and studies related with the revitalization of the monitoring of Turkey Creek watershed may provide decision support information. Accordingly, the Turkey Creek watershed research and study projects are being planned and implemented as a multi-collaborative approach considering both the needs for additional information as well as availability of resources.

\subsection{Data Acquisition}

The gauging station was reactivated in 2005, with the measurement of stream flow and rainfall as described above (see Sections 1, 2, and 3.2; http://waterdata.usgs.gov/sc/nwis/uv?site_no=02172035). Stream flow rates continue to be obtained by using stage heights using a Sutron datalogger connected to the pressure transducer at the bottom of the stream with a stage-discharge relationship developed by the USGS using frequent in situ manual velocity measurements with a Marsh-McBirney flowmeter. Rainfall is also measured with an automatic tipping bucket at the stream gauging station. A Campbell Scientific, Inc. weather station with a CR-10X datalogger was installed upstream in the watershed in October 2005 to monitor precipitation, air temperature, relative humidity, wind speed, and solar radiation). Later in August 2006, with support from the FMNF, four additional shallow wells (to depth of $3 \mathrm{~m}$ ) were also installed in four different soil types to monitor the water table on the south side of Turkey Creek watershed. In 2010, additional shallow groundwater well was installed on Wahee soil on the north side of Turkey Creek. Since late 2010 two smaller tributaries have been monitored for streamflow.

Stream water quality monitoring on this watershed was initiated with a bi-weekly grab sampling at the new gauging station in October, 2005 that was augmented later in June 2006 with the addition of a flow proportional sampling of storm events using an ISCO-4200 automatic sampler [83]. Both the manual grab and flow proportional samples for nutrients $\left(\mathrm{NO}_{3}-\mathrm{N}, \mathrm{NH}_{4}-\mathrm{N}\right.$, Total $\mathrm{N}$, and $\left.\mathrm{PO}_{4}\right)$ and some other cations $\left(\mathrm{Ca}^{+}, \mathrm{K}^{+}, \mathrm{Na}^{+}\right)$, and $\mathrm{Cl}^{-}$ from the ISCO auto samplers were analyzed in the Center's Soil and Water Chemistry laboratory in Charleston, SC until mid-2007 after which analysis is being conducted by the USDA Forest Service Coweeta Hydrologic Laboratory in Otto, North Carolina. Water quality for physical parameters (dissolved oxygen (DO), pH, temperature, turbidity, salinity, and conductivity) are measured in-situ every 3 - 4 weeks using a HYDROLAB's Eureca multi-sensor probe began in June 2006 also on a bi-weekly basis. Detailed procedures of the hydro-meteorologic and water quality monitoring have been described elsewhere [15] [18] [30] [32] [68] [83].

With the cooperation of College of Charleston, in December 2005 three sets of piezometers (a cluster of three groundwater wells) were installed along a cross-forest transect from northwest to southeast. One set was installed within the Turkey Creek watershed (adjacent to the weather station, and screened at depths below ground surface of $4.5 \mathrm{~m}, 6 \mathrm{~m}$, and $16 \mathrm{~m}$, respectively) and the other two piezometer sets were located outside the watershed. One piezometerset was installed in the Santee Experimental Forest watershed approximately $2 \mathrm{~km}$ NNW of the USGS Turkey Creek stream gage; the third piezometer set was installed about $15 \mathrm{~km}$ to the SE of the Turkey Creek stream gage [11].

Geographical Information Systems (GIS) data on topography from digital elevation models (DEMs), hydrography (drainage network), soils, vegetation, land use, and land management for the watershed are compiled primarily from the web sites of the SC DNR (www.dnr.sc.gov/GIS/gisdownload.html), and the Francis Marion National Forest (www.fs.fed.us/r8/fms/forest/Services/GIS/export.html). Similarly, aerial photographs for the study area were acquired from the National Forest for increments of five years starting in 1963, 1968, 1973, 1978, 1983, 1989 (before and after Hurricane Hugo), 1999 and thereafter are available from the National Forest). Preliminary work has been undertaken to refine the subwatershed boundaries and stream networks using LiDAR and high density aerial photography within the Francis Marion National Forest [33]. Ongoing work within the 
FMNF includes conducting and inventory of stream crossings and stream channels to provide improve aquatic information. A field survey was completed on the major tributaries and main channel including the road culverts and bridges using a surveyor's Trimble Global Positioning System (GPS) unit [32]. In mid-2011, LiDAR data for the study watershed were obtained from the Berkeley County dataset (J. Scurry, personal communication, 2011). The $1.5 \mathrm{~m}$ DEM created from the LiDAR data along with extensive field verifications for cross-drainage culverts along the roads bordering the watershed was used to obtain the new watershed drainage area of 5240 ha [34]. All other types of data have been described above in Sections 3.2 to 3.8. Data on hydro-meteorology, water quality, and land resources are now available through GIS-based data sharing web-portal at the site:

http://www.srs.fs.usda.gov/charleston/santee/data.html. Continued monitoring on this watershed in coming years will provide important information on long-term water budget, water yield, flooding pattern, and surface-subsurface water interactions needed for water management and appropriate ecological decisions. Furthermore, these data also help to better understand hydrologic effects of land use change and forest regeneration, after the impact of 1989 Hurricane Hugo [36]. Studies are already underway to examine seasonal storm event characteristics and dynamics, water budget, and ET of the forest ecosystem using historic data. Results from these studies will provide baseline information for an adjacent watershed (Quinby Creek) as well as be useful for comparison with other watersheds in the physiographic area. Current measurements on rainfall, weather, stream outflows, shallow and deep groundwater levels are providing data for further studies of the water balance, surface-subsurface water interactions, and the interactions of rainfall and soil types on shallow water table dynamics and stream outflow. Eventual correlations of moisture and soil data should help improve implementation guidance for ground disturbing activities. Understanding groundwater-surface water interactions will help the water resource managers deal with issues such as flood mitigation, groundwater exploitation, and biodiversity conservation, in a more integrated and sustainable manner [53]. A short term field sampling study to examine the impacts of bridge surface runoff at the Turkey Creek gauging station on the stream water quality downstream is underway in collaboration of the USGS with South Carolina Department of Transportation.

\subsection{Decision Support Process}

A physically-based, spatially distributed, watershed eco-hydrologic model, Soil and Water Assessment Tool (SWAT) [45] [84], was parameterized as a decision support tool for the Turkey Creek watershed [30] [32]. This model is capable of integrating various hydrological, ecological and biogeochemical processes occurring on a field-scale that can be extended into a large watershed/basin scale [85]-[87]. The simulation model was calibrated and validated using the watershed spatial data as well as temporal and spatial data on precipitation, weather, stream flow rates collected through 2010, and groundwater table. The validated model can then be used for its further application to evaluate management decisions related with anthropogenic and natural disturbances. The SWAT model has been used as a decision supporting tool to evaluate impacts of land use and climate change and management and basin wide water management [88] [89].

\subsection{Open Access and Transparency of Output}

The parameterized model, data for calibration, and simulation results will be made accessible to others including the public after a proper quality assurance review. This reporting will be implemented through web posting http://www.srs.fs.usda.gov/charleston/, reporting in cooperators' meetings, meetings and conferences of professional societies, progress reports to the cooperators, in addition to publication in conference proceedings and journal papers, and information bulletins.

\subsection{Integrated Modeling Approach}

It is very important that an integrated model be used to incorporate physically-based hydrologic, biogeochemical and ecological processes that are applicable to poorly drained, high water table soils followed by the flow routing schemes that consider wetland depressions, braided streams, backwater and tidal effects. Hydrologic processes on relatively low-gradient poorly drained coastal plain sites, like Turkey Creek watershed, are usually dominated by wetlands with variable shallow water table positions. Most of the outflows (surface runoff and subsurface drainage) from these watersheds drain from saturated areas where the water is at the surface or a shallow water table is present meaning that the otal outflow depends in part on the frequency and duration of 
flooding and also on the dynamics of the water table (hydroperiod), which are driven by rainfall substrate permeability and evapotranspiration (ET) [90]. We have chosen the SWAT model [85] as an integrated comprehensive model that has been extensively tested and applied for modeling runoff and evapotranspiration (water budget), erosion and sediment transport, groundwater, river hydrology, flooding (flood management), water chain, water quality (nutrients), evapotranspiration, ecological-environmental (harvesting, burning etc.), and economical parameters. For example, [84] recently demonstrated the applicability of the SWAT model in predicting daily stream flows from coastal Louisiana watersheds, which have primarily forested and agricultural land uses. [91] also used the SWAT to model point and diffuse source pollution of nitrate in a rural lowland catchment.

The model is currently being further refined using the new LiDAR-based, high resolution DEMs for subwatershed boundary and stream tributary delineation and other related model input parameters using the ArcSWAT9.3 platform. Available concept of HRUs (Hydrologic Response Unit) in the SWAT model is also used for the areas with specific management such as the open areas and private lands, wetlands for accurately assigning the parameters and simulating the processes. Hydraulic parameters needed for flow routing process were obtained from both the literature and also the stream and drainage network survey at the site. However, some uncertainty may exist for braided streams potentially with higher roughness. Soil hydraulic properties for major soil types are being used either from the measurements or from the published data for the region. Rainfall data is being used from three automatic gauges within and just outside the watershed. Data from the in-situ weather station as well as nearby station above forest canopy (WS 80) in a tower are being used for forest potential ET (PET) estimates. All other vegetation parameters were obtained either from the literature or some field measurements. The reliability of the SWAT model in predicting the stream flow processes on poorly drained soils published earlier by [30] on this watershed is being tested further. Results so far have been favorable. Furthermore, development of an analytical model to estimate daily water table dynamics as a function of daily rainfall, PET, and soil and vegetation parameters for major soil types on the watershed is underway.

\section{Developing Water Management Indicators}

Hydrologic and water management indicators are standard metrics obtained by measurements of streamflow and water quality sampling of chemical $\left(\mathrm{NO}_{3}-\mathrm{N}, \mathrm{NH}_{4}-\mathrm{N}\right.$, Total P, Total N, DOC, $\mathrm{Cl}, \mathrm{Ca}, \mathrm{K}, \mathrm{Mg}$, and $\mathrm{Na}$ ) and physical (pH, DO, temperature, turbidity, salinity, and specific conductivity) parameters. Stream flow rates can be analyzed to obtain the design maximum and minimum flow, flow frequency duration, mean runoff coefficient, water yield and storage including their variability. Alternatively, the proposed "Indicators of Hydrologic Alteration (IHA)" method is based upon an analysis of hydrologic data available either from existing measurement points within an ecosystem (such as at stream gauges or wells) or model-generated data [49]. In this method 32 parameters, organized into five groups, to statistically characterize hydrologic variation within each year provide information on ecologically significant features of surface and ground water regimes influencing aquatic, wetland, and riparian ecosystems. Results of a recently conducted survey of fish species counts can be found elsewhere [92], which may also serve as a stream biological indicator.

\section{Ecosystem Assessment}

The condition of the forest ecosystem within the watershed is assessed on a periodic basis through the forest planning and revision process described above and watershed condition assessment of national forest subwatersheds by the forest team of resource specialists [29]. In addition, aerial surveys are occasionally conducted and photos taken, when needed, to assess a) insect and disease outbreaks, b) changes in forest condition or cover, such as red-cockaded woodpecker habitat, and c) wildfire patrols. The physical, biological and cultural assessment approaches have been developed for each resource area by the National Forest to be consistent with law, regulation and quality resource management. All of the above data from this relatively undisturbed forested watershed can possibly be used as a "reference" for eco-hydrological and water quality assessments of developing watersheds in the coastal region. Additional knowledge produced from future interdisciplinary collaborations, coupled with the application of modern modeling techniques, will determine the accuracy and precision of future ecohydrological assessments [93]. 


\section{Summary}

This case study provides a comprehensive water resources assessment in terms of surface water and groundwater as related to the soils, geology, and vegetation for a 5240 ha forested watershed, one that is typical to the Atlantic Coastal Plain. The study also provides information on existing water resources knowledge including modeling integrated water resources management based on last 10 years of collaborative studies, administrative policy and decision process, and socio-economics as related to water resources management on this type of watershed assessment. Various types of data needs and acquisition including applications of socioeconomics were highlighted to respond to more complex, broader scale problems with cumulative ecohydrologic effects using an integrated watershed management approach on a larger watershed. The long-term eco-hydrologic data available for the study watershed after its revitalization in 2005 provided a sound scientific basis for multidisciplinary collaborators to advance the understanding of processes, characteristics, and their interactions on the lower coastal plain landscape, including its resiliency after an extreme hurricane event (Hugo) that occurred in 1989. Although the data and information generated from this study may be useful as a "reference" for comparison of coastal water resources and management issues, it is becoming increasingly clear that one example is helpful, but multi-site studies may be warranted to understand these complex systems in the face of climate change and sea level rise. The need for further research in several areas was highlighted, including 1) accurate partitioning of surface and subsurface flow, 2) ET dynamics, 3) monitoring for mercury and fecal coliform, 4) developing techniques to improve the forest health such as by prescribed fire or biomass treatment for fuel hazard reduction, 5) assessing ecosystem impacts of climate change and others to address the contemporary issues on this and other similar coastal watersheds.

\section{Acknowledgements}

Initial support for reestablishing the gauging station and the associated data collection, management, and analyses was provided by the USDA Forest Service and the National Council for Air and Stream Improvement, Inc. (NCASI). The reactivation of the watershed monitoring has been conducted in cooperation with the US Geological Survey, the College of Charleston, and the South Carolina Department of Transportation. This work was supported by the USDA Forest Service and partially by the NATO Committee on Challenges for Modern Society (CCMS) Integrated Water Management Program (IWM), University of Antwerp, Belgium. Authors would like to acknowledge Francis Marion National Forest, US Geological Survey, College of Charleston, South Carolina Department of Transportation, Agricultural University of Krakow and Warsaw University of Life Sciences in Poland, Clemson University, Florida A\&M University, for their various levels of support in this project. Thanks are also due to Lisa Wilson, Bray Beltran, Ileana La Torre Torres, Elizabeth Haley, former graduate students, respectively, at the College of Charleston, and Andy Harrison, Julie Arnold, and Matt Kraswoski (formerly), USDA Forest Service, Center for Forested Wetlands Research, for installing monitoring stations and data collection. The authors also express their thanks to USDA Forest Service Southern Research Station Civil Rights Committee for supporting travel grants to Joseph Amoah former PhD student at Florida A\&M University and Jose Martin former student at Gainesville State College, GA. Thanks are also due to Jose Martin for completing the LiDAR data processing for watershed delineation and his academic advisor Dr. Sudhanshu Panda for needed guidance. We also highly appreciate Dr. Paul Conrads at US Geological Survey and Dr. Daniel Hitchcock at Clemson University for their constructive comments in their review of this paper.

\section{References}

[1] Reice, S. (2005) Ecosystems, Disturbance and the Impact of Sprawl. In: Johnson, E.A. and Klemens, M.W., Eds., Nature in Fragments: The Legacy of Sprawl, Columbia University Press, New York, 90-108.

[2] Smith, H.R. (2012) Rich Swamps and Rice Grounds: The Specialization of Inland Rice Culture in the South Carolina Low Country, 1670-1861. PhD Dissertation, The University of Georgia, Athens.

[3] Dai, Z., Trettin, C. and Amatya, D.M. (2013) Effects of Climate Variability on Forest Hydrology and Carbon Sequestration on the Santee Experimental Forest in Coastal South Carolina. SRS-172, USDA Forest Service, Asheville, 32.

[4] Golden, H.E., Lane, C.R., Amatya, D., Bandilla, K., Raanan-Kiperwas, H., Knightes, C.D. and Ssegane, H. (2014) Hydrologic Connectivity between Geographically Isolated Wetlands and Surface Water Systems: A Review of Select Modeling Methods. Environmental Modeling \& Software, 53, 190-206. 
http://dx.doi.org/10.1016/j.envsoft.2013.12.004

[5] Doar, W.R. (2014) The Geologic Implications of the Factors That Affected Relative Sea-Level Positions in South Carolina During the Pleistocene and the Associated Preserved High-Stand Deposits. PhD Dissertation, University of South Carolina, Columbia.

[6] Messina, M.G. and Conner, W.H. (1997) Southern Forested Wetlands: Ecology and Management. CRC Press, Boca Raton.

[7] Amatya, D.M., Callahan, T.J. and Trettin, C.C. (2015) Synthesis of 10 Years of Hydrologic Studies on Turkey Creek Watershed. Proceedings of the 5th Interagency Conference on Research in the Watersheds, Charleston, 2-5 March 2015.

[8] Amatya, D.M., Skaggs, R.W. and Gregory, J.D. (1997) Evaluation of a Watershed Scale Forest Hydrologic Model. Agricultural Water Management, 32, 239-258. http://dx.doi.org/10.1016/S0378-3774(96)01274-7

[9] Aust, W.M., Reisinger, T.W., Burger, J.A. and Stokes, B.J. (1993) Soil Physical and Hydrological Changes Associated with Logging a Wet Pine Flat with Wide-Tired Skidders. Southern Journal of Applied Forestry, 17, 22-25.

[10] Amatya, D.M., Skaggs, R.W. and Gregory, J.D. (1996) Effects of Controlled Drainage on the Hydrology of Drained Pine Plantations in the North Carolina Coastal Plain. Journal of Hydrology, 181, 211-232. http://dx.doi.org/10.1016/0022-1694(95)02905-2

[11] Callahan, T.J., Vulava, V.M., Passarello, M.C. and Garrett, C.G. (2012) Estimating Groundwater Recharge in Lowland Watersheds. Hydrological Processes, 26, 2845-2855. http://dx.doi.org/10.1002/hyp.8356

[12] Epps, T.H., Hitchcock, D.R., Jayakaran, A.D., Loflin, D.R., Williams, T.M. and Amatya, D.M. (2013) Characterization of Storm Flow Dynamics of Headwater Streams in the South Carolina Lower Coastal Plain. Journal of the American Water Resources Association, 49, 76-89. http://dx.doi.org/10.1111/jawr.12000

[13] Slattery, M.C., Gares, P.A. and Phillips, J.D. (2006) Multiple Modes of Storm Runoff Generation in a North Carolina Coastal Plain Watershed. Hydrological Processes, 20, 2953-2969. http://dx.doi.org/10.1002/hyp.6144

[14] Amatya, D.M., Miwa, M., Harrison, C.A., Trettin, C.C. and Sun, G. (2006) Hydrology and Water Quality of Two First Order Forested Watersheds in Coastal South Carolina. ASABE Annual Conference, 22.

[15] Amatya, D.M., Callahan, T.J., Trettin, C.C. and Radecki-Pawlik, A. (2009) Hydrologic and Water Quality Monitoring on Turkey Creek Watershed, Francis Marion National Forest, South Carolina. ASABE Annual Conference, Reno.

[16] Burke, M.K. and Eisenbies, M.H. (2000) The Coosawhatchie Bottomland Ecosystem Study a Report on the Development of a Reference Wetland. SRS-38, USDA Forest Service, Asheville, 64.

[17] Harder, S.V., Amatya, D.M., Callahan, T.J., Trettin, C.C. and Hakkila, J. (2007) Hydrology and Water Budget for a Forested Atlantic Coastal Plain Watershed, South Carolina. Journal of the American Water Resources Association, 43, 563-575. http://dx.doi.org/10.1111/j.1752-1688.2007.00035.x

[18] La Torre Torres, I.B., Amatya, D.M., Sun, G. and Callahan, T.J. (2011) Seasonal Rainfall-Runoff Relationships in a Lowland Forested Watershed in the Southeastern USA. Hydrological Processes, 25, 2032-2045. http://dx.doi.org/10.1002/hyp.7955

[19] McCarthy, E.J., Skaggs, R.W. and Farnum, P. (1991) Experimental Determination of the Hydrologic Components of a Drained Forest Watershed. Transactions of the American Society of Agricultural Engineers, 34, 2031-2040. http://dx.doi.org/10.13031/2013.31833

[20] Pyzoha, J.E., Callahan, T.J., Sun, G., Trettin, C.C. and Miwa, M. (2008) A Conceptual Hydrologic Model for a Forested Carolina Bay Depressional Wetland on the Coastal Plain of South Carolina, USA. Hydrological Processes, 22, 2689-2698. http://dx.doi.org/10.1002/hyp.6866

[21] Riekerk, H., Jones, S.A., Morris, L.A. and Pratt, D.A. (1979) Hydrology and Water Quality of Three Small Lower Coastal Plain Forested Watersheds. Proceedings of the Soil Crop Science Society of Florida, 38, 105-111.

[22] Skaggs, R.W., Chescheir, G.M., Fernandez, G.P., Amatya, D.M. and Diggs, J. (2011) Effects of Land Use on Soil Properties and Hydrology of Drained Coastal Plain Watersheds. Transactions of the ASABE, 54, 1357-1365. http://dx.doi.org/10.13031/2013.39037

[23] Sun, G., Callahan, T.J., Pyzoha, J.E. and Trettin, C.C. (2006) Modeling the Climatic and Subsurface Stratigraphy Controls on the Hydrology of a Carolina Bay Wetland in South Carolina, USA. Wetlands, 26, 567-580. http://dx.doi.org/10.1672/0277-5212(2006)26[567:MTCASS]2.0.CO;2

[24] Sun, G., Lu, J., Gardner, D., Miwa, M. and Trettin, C.C. (2000) Water Budgets of Two Forested Watersheds in South Carolina. Spring Specialty Conference of American Water Resources Association, Middleburg, 199-202.

[25] Young, C.E. and Klawitter, R.A. (1968) Hydrology of Wetland Forest Watersheds. Proceedings of Hydrology in Water Resources Management, Clemson, 29-38. 
[26] Young, C.E. (1964) Precipitation-Runoff Relations of Small Forested Watersheds in the Coastal Plain. Wetland Hydrology Study Plan W-3, USDA Forest Service, Charleston, 23.

[27] Amatya, D.M. and Trettin, C.C. (2007) Annual Evapotranspiration of a Forested Wetland Watershed, South Carolina. ASABE Annual Conference, 4.

[28] Eidson, J.P., Lacy, C.M., Nance, L., Hansen, W.F., Lowery, M.A. and Hurley, N.M. (2005) Development of a 10- and 12-Digit Hydrologic Unit Code Numbering System. USDA Natural Resources Conservation Service, 38.

[29] USFS (2011) Watershed Condition Framework Technical Guide. FS-978, USDA Forest Service, 49.

[30] Amatya, D.M. and Jha, M.K. (2011) Evaluating Swat Model for a Low-Gradient Forested Watershed in Coastal South Carolina. Transactions of the ASABE, 54, 2151-2162. http://dx.doi.org/10.13031/2013.40671

[31] BCD-COG (2000) Water Quality Management Plan, Vol. II. A Report. Berkeley Charleston Dorchester Council of Governments, North Charleston, 11.

[32] Haley, E.B. (2007) Field Measurements and Hydrologic Modeling of the Turkey Creek Watershed, South Carolina. MS Thesis, College of Charleston, Charleston.

[33] Maceyka, A. and Hansen, W.F. (2015) Enhancing Hydrologic Mapping Using Lidar and High Resolution Aerial Photos on the Francis Marion National Forest in Coastal South Carolina. Proceedings of the 5th Interagency Conference on Research on Watersheds, Charleston.

[34] Amatya, D.M., Trettin, C., Panda, S. and Ssegane, H. (2013) Application of Lidar Data for Hydrologic Assessments of Low-Gradient Coastal Watershed Drainage Characteristics. Journal of Geographical Information System, 5, 175-191. http://dx.doi.org/10.4236/jgis.2013.52017

[35] Campbell, B.G. and Coes, A.L. (2010) Groundwater Availability in the Atlantic Coastal Plain of North and South Carolina. Professional Paper 1773, US Geological Survey, Reston, 241.

[36] Hook, D.D., Buford, M.A. and Williams, T.M. (1991) Impact of Hurricane Hugo on the South Carolina Coastal Plain Forest. Journal of Coastal Research, 8, 291-300.

[37] SCDNR (2009) South Carolina Water Resources Assessment. South Carolina Department of Natural Resources, Columbia.

[38] Barker, R.A. and Pernik, M. (1994) Regional Hydrology and Simulation of Deep Ground-Water Flow in the Southeastern Coastal Plain Aquifer System in Mississippi, Alabama, Georgia, and South Carolina. Professional Paper 1410C, US Geological Survey.

[39] Colquhoun, D.J. (1974) Cyclic Surficial Stratigraphic Units of the Middle and Lower Coastal Plain, Central South Carolina. In: Post-Miocene Stratigraphy, Central and Southern Atlantic Coastal Plain, Utah State University Press, Logan.

[40] NRCS (1980) Soil Survey Report of Berkeley County, South Carolina. US Department of Agriculture, Natural Resources Conservation Service. USDA Natural Resources Conservation Service, 94.

[41] Law, D. (2006) USDA Forest Service. Columbia.

[42] Hargreaves, G.H. and Samani, Z.A. (1985) Reference Crop Evapotranspiration from Temperature. Applied Engineering in Agriculture, 1, 96-99. http://dx.doi.org/10.13031/2013.26773

[43] Monteith, J.L. (1965) Evaporation and Environment. Symposia of the Society for Experimental Biology, 19, $205-234$.

[44] Amatya, D.M. and Radecki-Pawlik, A. (2007) Flow Dynamics of Three Experimental Forested Watersheds in Coastal South Carolina, U.S.A. Acta Scientiarium Polonorum Formatio Cirtumiectus, 6, 3-16.

[45] Arnold, J.G., Srinivasan, R., Muttiah, R.S. and Williams, J.R. (1998) Area Hydrologic Modeling and Assessment Part I: Model Development. Journal of the American Water Resources Association, 34, 73-89. http://dx.doi.org/10.1111/j.1752-1688.1998.tb05961.x

[46] Marion, D.A., Sun, G., Caldwell, P.V., Chelcy, F., Conrads, P.A., Laird, S.G., Dai, Z., Meyers, J.A.M. and Trettin, C. (2013) Managing Forest Water Quantity and Quality under Climate Change. In: Vose, J. and Kleipzig, K., Eds., Climate Change Adaptation and Mitigation Management Options: A Guide for Natural Resource Managers in Southern Forest Ecosystems, CRC Press, Boca Raton, 496. http://dx.doi.org/10.1201/b15613-10

[47] Feaster, T.D., A.J., G. and Weaver, J.C. (2009) Magnitude and Frequency of Rural Floods in the Southeastern United States, 2006. Scientific Investigations Report 2009-5156, US Geological Survey, 226.

[48] Benson, M.A. and Carter, R.W. (1973) A National Study of the Streamflow Data-Collection Program. Water-Supply Paper 2208, US Geological Survey, 44.

[49] Richter, B.D., Baumgartner, J.V., Powell, J. and Braun, D.P. (1996) A Method for Assessing Hydrologic Alteration within Ecosystems. Conservation Biology, 10, 1163-1174. http://dx.doi.org/10.1046/j.1523-1739.1996.10041163.x

[50] Amatya, D.M., Harrison, C.A. and Trettin, C.C. (2014) Comparison of Potential Evapotranspiration Using Three Me- 
thods for a Grass Reference and a Natural Forest in Coastal Plain of South Carolina. Proceedings of the 2014 South Carolina Water Resources Conference, Columbia.

[51] Amatya, D.M. and Trettin, C.C. (2010) Outflow Characteristics of a Naturally Drained Forested Watershed in Coastal South Carolina. 9th International Drainage Symposium, Held Jointly with CIGR and CSBE/SCGAB, Quebec City.

[52] U.S. EPA (2015) Connectivity of Streams and Wetlands to Downstream Waters: A Review and Synthesis of the Scientific Evidence (Final Report). U.S. Environmental Protection Agency, Washington, DC, EPA/600/R-14/475F. http://cfpub.epa.gov/ncea/cfm/recordisplay.cfm?deid=296414

[53] Schot, P. and Winter, T. (2006) Groundwater-Surface Water Interactions in Wetlands for Integrated Water Resources Management. Journal of Hydrology, 30, 261-263. http://dx.doi.org/10.1016/j.jhydrol.2005.07.021

[54] Colquhoun, D.J., Gardner, R.L. and Steele, K.B. (1986) Recharge-Discharge Area, Piezometric Surface and Water Chemistry Characteristics of the Tertiary Limestone Aquifer System in South Carolina. Water Resources Research Institute, Clemson.

[55] Meadows, J.K. (1987) Ground-Water Conditions in the Santee Limestone and Black Mingo Formation near Moncks Corner, Berkeley County, South Carolina. WRC-156, South Carolina Water Resources Commission, Columbia, 38.

[56] Bouwer, H. (1989) Bouwer and Rice Slug Test-An Update: Bouwer, H Ground WaterV27, N3, May-June 1989, P304-309. International Journal of Rock Mechanics and Mining Sciences \& Geomechanics Abstracts, 26, 305. http://dx.doi.org/10.1016/0148-9062(89)91577-5

[57] Bouwer, H. and Rice, R.C. (1976) A Slug Test for Determining Hydraulic Conductivity of Unconfined Aquifers with Completely or Partially Penetrating Wells. Water Resources Research, 12, 423-428. http://dx.doi.org/10.1029/WR012i003p00423

[58] Aucott, W.R. and Speiran, G.K. (1985) Potentiometric Surfaces of November 1982 and Declines in the Potentiometric Surfaces between the Period Prior to Development and November 1982 for the Coastal Plain Aquifers of South Carolina. Water-Resources Investigations Report 84-4215, US Geological Survey.

[59] Newcome Jr., R. (1989) Ground-Water Resources of South Carolina’s Coastal Plain. WRC-167, South Carolina Water Resources Commission, Columbia.

[60] Weems, R.E. and Lemon, E.M. (1993) Geology of the Cainhoy, Charleston, Fort Moultrie, and North Charleston Quadrangles, Charleston and Berkeley Counties, South Carolina. Misc. Invest. Ser. Map I-1935, US Geological Survey, Reston.

[61] Plewa, T. and Hansen, W. (2003) Current Status of Water Quality Information on the Francis Marion National Forest. USDA Forest Service, Columbia, 43.

[62] Muwamba, A., Amatya, D.M., Trettin, C. and Glover, J. (2015) Comparing Nutrient Exports from 1st, 2nd, and 3rd Order Watersheds on South Carolina Atlantic Coastal Plain. Proceedings of the 5th Interagency Conference on Research in the Watersheds, North Charleston.

[63] Bureau, U.S.C. (2010) Census of Population, State \& County Quick Facts: Berkeley County, South Carolina. Washington DC.

[64] USFS (2015) Francis Marion National Forest Plan Revision Environmental Impact Statement. USDA Forest Service (under Internal Review before Public Release).

[65] Dai, Z., Li, C., Trettin, C.C., Sun, G., Amatya, D.M. and Li, H. (2010) Sensitivity of Stream Flow and Water Table Depth to Potential Climatic Variability in a Coastal Forested Watershed. Journal of the American Water Resources Association, 46, 1036-1048. http://dx.doi.org/10.1111/j.1752-1688.2010.00474.X

[66] Miwa, M., Gardner, D.L., Bunton, C.S., Humphreys, R. and Trettin, C.C. (2003) Characterization of Headwater Stream Hydrology in the Southeastern Lower Coastal Plain. USDA Forest Service, Charleston.

[67] Griffin, M.P., Callahan, T.J., Vulava, V.M. and Williams, T.M. (2014) Storm-Event Flow Pathways in Lower Coastal Plain Forested Watersheds of the Southeastern United States. Water Resources Research, 50, 8265-8280. http://dx.doi.org/10.1002/2014WR015941

[68] Garrett, C.G., Vulava, V.M., Callahan, T.J. and Jones, M.L. (2012) Groundwater-Surface Water Interactions in a Lowland Watershed: Source Contribution to Stream Flow. Hydrological Processes, 26, 3195-3206. http://dx.doi.org/10.1002/hyp.8257

[69] Griffin, M.P., Epps, T.H., Callahan, T.J., Vulava, V.M. and Hitchock, D.R. (2012) Using Water Chemistry Data to Assess Stormwater Pathways in Lowland Watersheds. Proceedings of the 2012 South Carolina Water Resources Conference, Columbia.

[70] Amoah, J.K.O. (2008) A New Methodology for Estimating Watershed-Scale Depression Storage. PhD Dissertation, Florida A\&M University, Tallahassee.

[71] Amoah, J.K.O., Amatya, D.M. and Nnaji, S. (2013) Quantifying Watershed Surface Depression Storage: Determina- 
tion and Application in a Hydrologic Model. Hydrological Processes, 27, 2401-2413. http://dx.doi.org/10.1002/hyp.9364

[72] Dai, Z., Li, C., Trettin, C., Sun, G., Amatya, D. and Li, H. (2010) Bi-Criteria Evaluation of the Mike She Model for a Forested Watershed on the South Carolina Coastal Plain. Hydrology and Earth System Sciences, 14, 1033-1046. http://dx.doi.org/10.5194/hess-14-1033-2010

[73] Amatya, D.M., Ssegane, H., Harrison, C.A. and Trettin, C.C. (2015b) Testing Resiliency of Hydrologic Dynamics of a Paired Forested Watershed after a Hurricane in Atlantic Coastal Plain.

[74] Dai, Z., Li, C., Trettin, C.C., Sun, G., Amatya, D.M. and Li, H. (2011) Climate Variability and Its Impact on Forest Hydrology on South Carolina Coastal Plain, USA. Atmosphere, 2, 330-357. http://dx.doi.org/10.3390/atmos2030330

[75] Jayakaran, A.D., Williams, T.M., Ssegane, H., Amatya, D.M., Song, B. and Trettin, C.C. (2014) Hurricane Impacts on a Pair of Coastal Forested Watersheds: Implications of Selective Hurricane Damage to Forest Structure and Streamflow Dynamics. Hydrology and Earth System Sciences, 18, 1151-1164. http://dx.doi.org/10.5194/hess-18-1151-2014

[76] Wilson, L., Amatya, D.M., Callahan, T.J. and Trettin, C.C. (2006) Hurricane Impact on Stream Flow and Nutrient Exports for a First Order Forested Watershed of the Lower Coastal Plain, South Carolina. Proceedings of the 2nd International Conference on Research on Watersheds, Coweeta.

[77] NCDWQ (2005) Identification Methods for the Origins of Intermittent and Perennial Streams, Version 3.1. North Carolina Division of Water Quality, Raleigh.

[78] Trettin, C.C., Amatya, D.M., Kaufman, C., Levine, N. and Morgan, R.T. (2008) Recognizing Change in Hydrologic Functions and Pathways Due to Historical Agricultural Use-Implications to Hydrologic Assessment and Modeling. Proceedings of the 3rd International Conference on Research in the Watersheds, Aspen.

[79] Czwartacki, B.J., Trettin, C.C. and Callahan, T.J. (2015) Water Dynamics along the Terrestrial Boundary of a Tidal Freshwater Forested Wetland. Wetlands (Submitted for Review December 2014).

[80] USFS (2003) Roads Analysis: Francis Marion National Forest. USDA Forest Service, Columbia, 36.

[81] McLaughlin, K., Ragus, J. and Hansen, W.F. (2002) Soil and Water Conservation Practices Guide. USDA Forest Service, Atlanta, 149.

[82] Amatya, D., Harrison, C. and Trettin, C. (2007) Water Quality of Two First Order Forested Watersheds in Coastal South Carolina. In: Watershed Management to Meet Water Quality Standards and Total Maximum Daily Load, Proceedings of the ASABE Annual Conference, San Antonio.

[83] Amatya, D.M., Callahan, T.J., Radecki-Pawlik, A., Drewes, P., Trettin, C. and Hansen, W.F. (2008) Hydrologic and Water Quality Monitoring on Turkey Creek Watershed, Francis Marion National Forest, South Carolina. Proceedings of the 2008 South Carolina Water Resources Conference, Charleston.

[84] Wu, K. and Xu, Y.J. (2006) Evaluation of the Applicability of the Swat Model for Coastal Watersheds in Southeastern Louisiana. Journal of the American Water Resources Association, 42, 1247-1260. http://dx.doi.org/10.1111/j.1752-1688.2006.tb05610.x

[85] Arnold, J.G. and Srinivasan, R. (1998) A Continuous Catchment-Scale Erosion Model. In: Boardman, J. and Favis-Mortlock, D., Eds., Modelling Soil Erosion by Water, Springer Berlin, Heidelberg, 413-427. http://dx.doi.org/10.1007/978-3-642-58913-3_31

[86] Miller, S.N., Kepner, W.G., Mehaffey, M.H., Hernandez, M., Miller, R.C., Goodrich, D.C., Kim Devonald, K., Heggem, D.T. and Miller, W.P. (2002) Integrating Landscape Assessment and Hydrologic Modeling for Land Cover Chane Analysis. Journal of the American Water Resources Association, 38, 915-929. http://dx.doi.org/10.1111/j.1752-1688.2002.tb05534.x

[87] Santhi, C., Arnold, J.G., Williams, J.R., Dugas, W.A. and Hauck, L. (2002) Application of a Watershed Model to Evaluate Management Effects on Point and Non-Point Source Pollution. Transactions of the ASAE, 44, 1559-1570.

[88] Fohrer, N., Eckhardt, K. and Haverkamp, S. (1999) Applying the Swat Model as a Decision Support Tool for Land Use Concepts in Peripheral Regions in Germany. Proceedings of the 10th International Soil Conservation Organization Meeting, West Lafayette, 994-999.

[89] Sophocleous, M.A., Koelliker, J.K., Govindaraju, R.S., Birdie, T., Ramireddygari, S.R. and Perkins, S.P. (1999) Integrated Numerical Modeling for Basin-Wide Water Management: The Case of the Rattlesnake Creek Basin in SouthCentral Kansas. Journal of Hydrology, 214, 179-196. http://dx.doi.org/10.1016/S0022-1694(98)00289-3

[90] Amatya, D.M., Trettin, C.C., Skaggs, R.W., Burke, M.K., Callahan, T.J., Sun, G., Nettles, J.E. and Parsons, J.E. (2005) Five Hydrologic Studies Conducted by or in Cooperation with the Center for Forested Wetlands Research. SRS-40, USDA Forest Service, Asheville, 24.

[91] Lam, Q.D., Schmalz, B. and Fohrer, N. (2010) Modelling Point and Diffuse Source Pollution of Nitrate in a Rural Lowland Catchment Using the Swat Model. Agricultural Water Management, 97, 317-325. 
http://dx.doi.org/10.1016/j.agwat.2009.10.004

[92] Krause, C. and Roghair, C. (2010) Fish Inventory Results for Coastal Plain Streams on the Francis Marion National Forest, South Carolina. USDA Forest Service, Blacksburg, 28.

[93] Hawkins, C.P., Olson, J.R. and Hill, R.A. (2010) The Reference Condition: Predicting Benchmarks for Ecological and Water-Quality Assessments. Journal of the North American Benthological Society, 29, 312-343. http://dx.doi.org/10.1899/09-092.1 